\title{
Analysis of a Rare Honey Sample From Tuzluca/Iğdır Region
}

\section{Hakan KAYGUSUZ ${ }^{1 *}$}

\begin{abstract}
Turkey has a wide variety of honey products and most of the honeys are endemic. There are many endemic honey samples in Anatolia that have not been investigated yet. Since natural honey has special benefits due to its many bioactive ingredients, it is still a challenge to classify and characterize different honey samples. In this study, an endemic and rare honey sample from the mountainous and almost uninhabited region of Tuzluca, Iğdır is reported. Honey sample is characterized by the means of antioxidant and antidiabetic capacities, nitrite and nitrate content, fructose/glucose ratio. Results indicate that the reported honey sample has unique characteristics.
\end{abstract}

Keywords: honey, capillary electrophoresis, antioxidant, antidiabetic, Iğdır

${ }^{1}$ Hakan KAYGUSUZ (Orcid ID: 0000-0001-9336-1902), Altınbaş Üniversitesi, Mühendislik ve Doğa Bilimleri Fakültesi, Temel Bilimler Bölümü, İstanbul, Türkiye

*Sorumlu Yazar/Corresponding Author: Hakan KAYGUSUZ, e-mail: hakan.kaygusuz@altinbas.edu.tr 


\section{INTRODUCTION}

Honey is known as a valuable nutritional and medicinal food source of natural origin. Its composition is associated with the floral origins, geography as well as presence of pollutants. Turkey is a home to more than 12.000 native plant species and of nearly 450 species are known as honey plants (Sorkun 2008, Özkök et al. 2016). Turkey is second largest honey producer and Anatolia has one of the richest flora (Kaygusuz et al. 2016). In recent years there is an interest to study the characteristics of Turkish honeys and pollen samples. Recent studies include biochemical analysis of Mutki/Bitlis with a good total phenolic concentrations (Özşahin Kireççi and Kireççi 2018), chestnut honeys from Black Sea region with a high fructose+glucose content (Dağ et al. 2017), dandelion (Taraxacum) honey from Bingöl as a new record in Turkey (Özenirler et al. 2018), characterization multifloral honeys of 6 different Sinop districts (Özler 2015), microbiological and parasitological analysis of honey samples from Istanbul (Dümen et al. 2013), volatile compound determination in pine honeys from MuğlaMarmaris region (Silici 2011), characterization of multifloral honeys from Pervari/Siirt (Erez et al. 2015), physicochemical analysis of multifloral samples from Konya and Karaman (Özler et al. 2019), 23 different monofloral honeys across Turkey including Antalya, Ordu, Van, Mardin, Adana, Istanbul, Batman, Konya Izmir, Hatay and Muğla (Gül and Pehlivan 2018), and monofloral honeys from Muğla, Kırklareli, Trabzon, Bayburt, Ordu and Isparta (Kaygusuz et al. 2016), an interesting study reports biomonitoring of pollutants in industrial districts of Izmir (Aliağa) by using honey bees and propolis (Matin et al. 2016), properties of Jerusalem thorn honey was investigated for Bursa, Edirne and Kurklareli (Malkoç et al. 2019) as well as honey from Aydın (Ünübol Aypak et al. 2019). Such studies are expected to increase in the upcoming years since Anatolian honey sources are numerous and needs to be studied for further discoveries and analyses. Recently honey is reported as an antidiabetic agent (Erejuwa et al. 2012) and it is already known to have good antioxidant characteristics.

In the present paper, properties of a rare honey sample from a mountainous and sparsely populated village of Tuzluca, Iğdır are reported and discussed. The region has an elevation of $\sim 2200 \mathrm{~m}$ above sea level. Antioxidant and antidiabetic properties of the sample was investigated as well as some quality parameters such as fructose to glucose ratio and nitrate/nitrite content.

\section{MATERIALS AND METHODS}

\section{Materials}

Honey samples were obtained from Ombulak village in Tuzluca (Iğdır, Turkey). Honey samples were of multifloral origin and were harvested in July 2019 season. $\alpha$-glucosidase, p-nitrophenyl- $\alpha$-Dglucopyranoside substrate, $\mathrm{D}(+)$ glucose, $\mathrm{D}(+)$ fructose and genistein were from from Sigma Chemical Co. (Steinheim, Germany). 1,1-diphenyl-2-picrylhydrazyl (DPPH), sodium nitrite, potassium nitrate, formic acid, sodium sulfate, sodium hydroxide, sodium carbonate, sodium dihydrogen phosphate dihydrate and disodium hydrogen phosphate dodecahydrate were from Merck (Darmstadt, Germany). Glycylglycine were from Fluka (Buchs, Switzerland) and acetonitrile was obtained from J. T. Baker (Deventer, Netherlands). All reagents were used without any further purification

\section{Capillary electrophoresis}

Nitrite-nitrate and sugar analyses were conducted using an Agilent 1600 capillary electrophoresis system (Waldbronn, Germany) equipped with a diode-array detector. Uncoated fused silica capillaries with $50 \mu \mathrm{m}$ internal diameter (Polymicro Technology, Phoenix, AZ, USA) were used with the total length of $65 \mathrm{~cm}$ and active length of $50 \mathrm{~cm}$. 
In order to prepare the honey samples for capillary electrophoresis, $0.1 \mathrm{~g}$ of honey was mixed with $10 \mathrm{~mL}$ of deionized water and stirred at $300 \mathrm{rpm}$ for 30 minutes at room conditions. After mixing completely, samples were filtered using microfilters of $0.45 \mu \mathrm{m}$ pore size. The resulting filtrate was directly injected for nitrite and nitrate analysis. On the other hand, for sugar analysis the filtrate was diluted two times.

A capillary zone electrophoresis method developed for simultaneous determination of nitrate and nitrite in food samples was employed (Kalaycıoğlu and Erim 2016). Pre-optimized conditions in this method were as follows: $30 \mathrm{mmol} / \mathrm{L}$ formic acid solution at $\mathrm{pH} 4.0$ with $30 \mathrm{mmol} / \mathrm{L}$ sodium sulfate was used as buffer; sample was injected at 50 mbar for $160 \mathrm{~s}$ under a separation voltage of $-25 \mathrm{kV}$ and at 25 ${ }^{\circ} \mathrm{C}$. Here, sodium sulfate in the buffer increases the conductivity of the buffer zone and provides sample stacking. Therefore, a high volume of injection was possible. Detection was done spectrometrically at $210 \mathrm{~nm}$. The capillary was subsequently flushed for 2 minutes with $0.1 \mathrm{~mol} / \mathrm{L}$ sodium hydroxide solution, water and the buffer between each run.

For the analysis of sugars, the capillary electrophoretic method developed for determination of carbohydrates was used. This method was successfully employed for pollen and honey samples (Kaygusuz et al. 2016, Kalaycioğlu et al. 2017b) and other food samples (Kolayli et al. 2010, Kalaycioğlu and Erim 2017) before. Here glycylglycine dipeptide is used as the seperation electrolyte, without the necessity to derivatize the analytes. Predefined optimal conditions were used as follows: 50 $\mathrm{mmol} / \mathrm{L}$ glycylglycine at $\mathrm{pH} \sim 12.5$. Samples were injected at $5 \mathrm{kPa}$ for $6 \mathrm{~s}$ from the anodic end under a separation voltage of $25 \mathrm{kV}$. Signal wavelength was $350 \mathrm{~nm}$ with a reference of $207 \mathrm{~nm}$.

For all capillary electrophoresis analyses, the amounts of the analytes in the samples were calculated using calibration curves. All measurements were of at least triplicates.

\section{Antioxidant and antidiabetic activity}

Antidiabetic and antioxidant activity measurements were carried out on a 96-well BioTek Power Wave XS microplate reader (Winooski, VT, USA).

$\alpha$-Glucosidase enzyme inhibitory activities were studied by a slightly modified method of Shai et al. (Shai et al. 2011, Kalaycioğlu et al. 2018). Here $50 \mu \mathrm{L}$ of $\mathrm{pH} 6.8$ phosphate buffer, $10 \mu \mathrm{L} \alpha$ Glucosidase $(0.5 \mathrm{U} / \mathrm{mL}$ in phosphate buffer) and $20 \mu \mathrm{L}$ of diluted honey samples $(10,25,50,100 \mu \mathrm{g} / \mathrm{mL})$ were preincubated for $15 \mathrm{~min}$ at $37 \mathrm{oC}$. After this step, enzymatic reaction was started by adding $20 \mu \mathrm{L}$ of $5 \mathrm{mmol} / \mathrm{L}$ p-nitrophenyl- $\alpha$-D-glucopyranoside substrate. After 20 minutes of incubation, reaction was stopped by adding $100 \mathrm{mmol} / \mathrm{L}$ of $50 \mu \mathrm{L} \mathrm{Na} 2 \mathrm{CO} 3$ solution. Released p-nitrophenol was monitored at $405 \mathrm{~nm}$ using the microplate reader. Typical angiogenesis inhibitor, genistein, was also tested as the reference. The system without any test material was employed as the control.

The free radical-scavenging activities were studied by the modified DPPH assay (Blois 1958, Kalaycıoglu et al. 2017a). This method is based on the monitoring the decreasing absorption of DPPH radical at $517 \mathrm{~nm} .90 \mu \mathrm{L}$ of $0.1 \mathrm{mmol} / \mathrm{L}$ DPPH solution was added to $10 \mu \mathrm{L}$ sample solution and absorbance at $517 \mathrm{~nm}$ was measured $30 \mathrm{~min}$ later. Results were compared with the synthetic antioxidant BHA (Butylated hydroxyanisole). All calculations were done using the calibration curves for microplate readings.

\section{RESULTS AND DISCUSSION}

Figure 1 shows the electropherogram of the honey sample for nitrate and nitrite analysis, where the upper electropherogram represents the sample spiked with $12.5 \mu \mathrm{mol} / \mathrm{L}$ standard nitrate and nitrite 
and the lower electropherogram is the sample only. Calibration curves were plotted by the addition of acetonitrile $(7.5 \% \mathrm{v} / \mathrm{v})$ to the nitrite and nitrate standards. Correlation coefficient, limit of detection (signal-to-noise ratio: 3 ) and limit of quantification (signal-to-noise ratio: 10) were calculated as shown in Table 1.

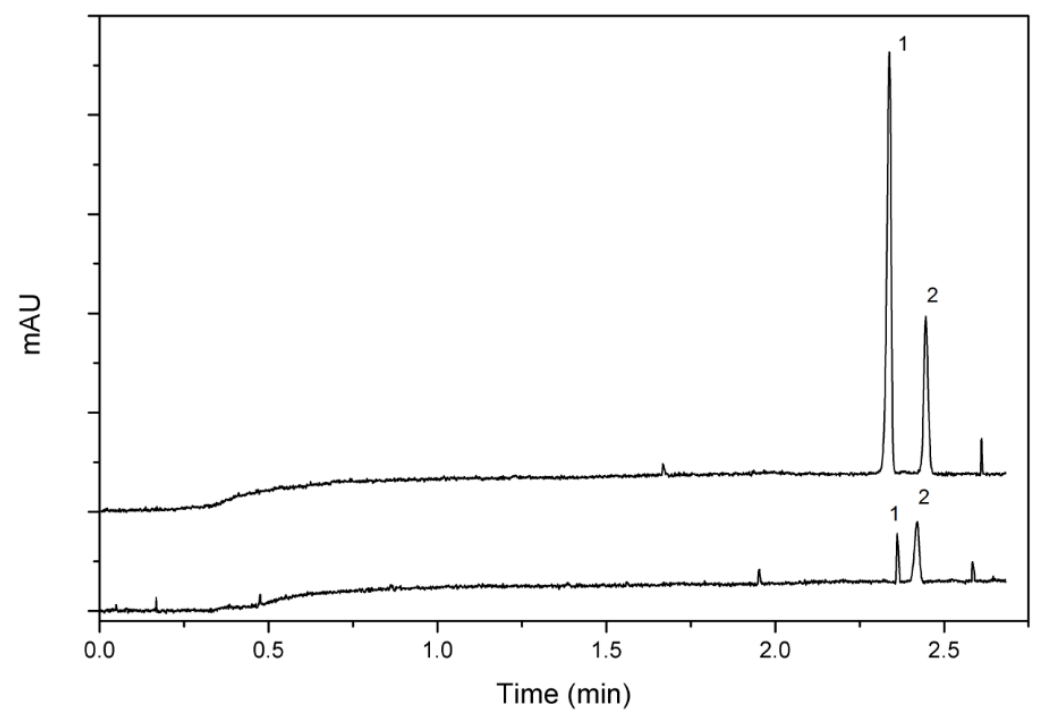

Figure.1. Electropherogram of the honey sample (bottom) and honey sample spiked with $12.5 \mu \mathrm{mol} / \mathrm{L}$ standard nitrate and nitrite solutions (top). Running potential: $-25 \mathrm{kV}$, detection at $210 \mathrm{~nm}$, under the buffer of $30 \mathrm{mmol} / \mathrm{L}$ formic acid, $30 \mathrm{mmol} / \mathrm{L}$ $\mathrm{Na}_{2} \mathrm{SO}_{4}$ and $\mathrm{pH}$ 4.0. Peaks 1: nitrate, 2: nitrite.

Table 1. Analytical parameters of nitrate and nitrite determination

\begin{tabular}{lll}
\hline Parameter & Nitrate & Nitrite \\
\hline Correlation coefficient of regression & 0.999 & 0.999 \\
Limit of detection, $\mathrm{LOD}(\mu \mathrm{mol} / \mathrm{L})$ & 0.50 & 1.35 \\
Limit of quantification, $\mathrm{LOQ}(\mu \mathrm{mol} / \mathrm{L})$ & 1.85 & 4.56 \\
\hline
\end{tabular}

According to the results, nitrate and nitrate concentrations in the injected sample were found as $0.5597 \pm 0.00174 \mu \mathrm{mol} / \mathrm{L}$ and $4,140 \pm 0,123 \mu \mathrm{mol} / \mathrm{L}$, respectively. These values are corresponding to $3.47 \pm 0.01 \mathrm{mg} / \mathrm{kg}$ of nitrate and $19.05 \pm 0.57 \mathrm{mg} / \mathrm{kg}$ of nitrite in the honey.

Figure 2 shows the electropherogram of the honey sample for glucose and fructose analysis. Correlation coefficient, LOD and LOQ for glucose and fructose analyses were listed in Table 2.

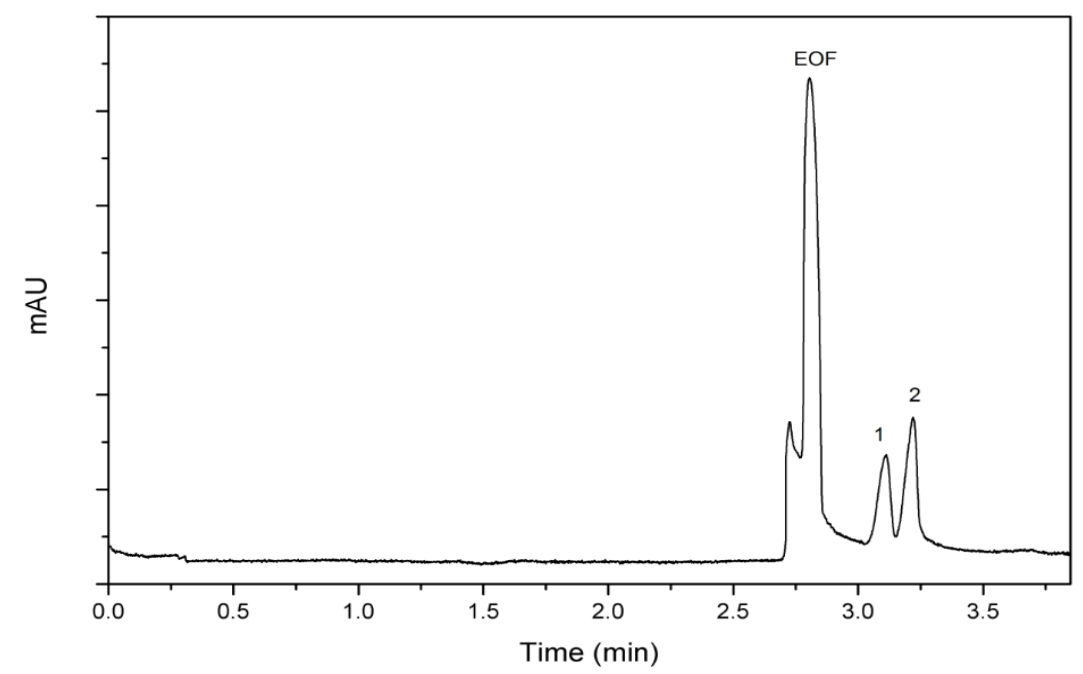

Figure 2. Electropherogram of the honey sample. Running potential: $25 \mathrm{kV}$, detection at $350 \mathrm{~nm}$, under the presence of $50 \mathrm{mmol} / \mathrm{L}$ glycylglycine at $\mathrm{pH}$ 12.5. Peaks 1: EOF: electroosmotic flow, 1: glucose, 2: fructose. 
Table 2. Analytical parameters of glucose and fructose determination

\begin{tabular}{lll}
\hline Parameter & Glucose & Fructose \\
\hline Correlation coefficient of regression & 0.995 & 0.991 \\
Limit of detection, LOD $(\mathrm{mg} / \mathrm{L}, \mathrm{ppm})$ & 26 & 30 \\
Limit of quantification, $\mathrm{LOQ}(\mathrm{mg} / \mathrm{L}, \mathrm{ppm})$ & 96 & 111 \\
\hline
\end{tabular}

According to the results, glucose and fructose concentrations in the injected sample were found as $418 \pm 4 \mathrm{mg} / \mathrm{g}$ and $468 \pm 3 \mathrm{mg} / \mathrm{g}$ of honey, respectively. Total amount of sugars in the honey sample was therefore $886 \mathrm{mg} / \mathrm{g}$ and fructose/glucose $(\mathrm{F} / \mathrm{G})$ ratio is 1.12 .

$\alpha$-Glucosidase inhibitory assay (IC50, in $\mu \mathrm{g} / \mathrm{mL}$ ) of the sample and genistein are found as $10.5 \pm$ 0.56 and $5.50 \pm 0.70 \mu \mathrm{g} / \mathrm{mL}$, respectively. IC50 - DPPH of the sample is found as $74.48 \pm 0.76 \mu \mathrm{g} / \mathrm{mL}$.

Table 3. Results of $\alpha$-Glucosidase inhibitory assay and DPPH.

\begin{tabular}{lcc}
\hline Analyte & $\mathrm{IC}_{50}$ of $\alpha$-Glucosidase inhibitory assay $(\mu \mathrm{g} / \mathrm{mL})$ & $\mathrm{IC}_{50}$ for DPPH $(\mu \mathrm{g} / \mathrm{mL})$ \\
\hline Honey sample & $10.5 \pm 0.56$ & $74.48 \pm 0.76$ \\
Genistein standard & $5.50 \pm 0.70$ & - \\
BHA standard[32] & - & $57.71 \pm 0.55$ \\
Multifloral honey from Hakkari [32] & - & $61.78 \pm 0.56$ \\
Citrus honey from Antalya [32] & - & $82.07 \pm 0.96$ \\
Clover honey from Diyarbakir [32] & - & $88.97 \pm 0.98$ \\
\hline
\end{tabular}

Nitrite and nitrate are among the natural constituents of various food sources, namely vegetables and many others, as well as these are classified as food additivfundes for meat products (Kalaycioğlu and Erim 2019). Nitrate and nitrite content of honey was previously evaluated (Beretta et al. 2010). It is reported that humans consume up to $8.7 \mathrm{mg}$ of nitrite per person per day and the most of the consumption is related to dietary intake of cured meat (Anonymous 2003). Other nitrite-rich foods include vegetables such as spinach and lettuce. There is a concern on nitrite due to possible carcinogenic effects for over a long period, on the other hand, most nitrite is endogenously converted from nitrate, thus plays an important role in the nitric oxide (NO) metabolic product cycle (Ma et al. 2018) and recent reports indicate that there is no relation between nitrate and nitrite intake and stomach cancer (Bryan et al. 2012) as well as there is a beneficial side of the nitrates and nitrites in cardiovascular health (Lundberg et al. 2011). According to the results in the present study, the honey of Ombulak/Tuzluca region contains more nitrite than nitrate. Although the nitrite concentration much lower than vegetables such as spinach and lettuce (Iammarino et al. 2014) a honey sample with more nitrite than nitrate is not common.

Antioxidant activity of the honey is evaluated using the DPPH assay. According to the results, IC50 of the sample is found as $74.48 \pm 0.76 \mu \mathrm{g} / \mathrm{mL}$ where the BHA is reported as $57.71 \pm 0.55 \mu \mathrm{g} / \mathrm{mL}$. When compared to Turkish honeys from very different locations (Kivrak and Kivrak 2017), Ombulak/Tuzluca honey is among the honeys have an upper-average antioxidant capacity. In addition to antioxidant characteristics, antidiabetic activity was found as $10.5 \pm 0.56$, which corresponds to 0.52 times the activity of Genistein standard, which indicates a good antidiabetic property. F/G ratio of the honey was found as 1.12, which indicates that the honey crystallizes slowly since F/G values above 1.0 indicate a slower crystallization (El Sohaimy et al. 2015, Radia et al. 2015). F/G ratio is typical for multifloral honeys and is within the quality limits of Turkish Food Codex Communiqué on Honey (1.0$1.4)$.

\section{CONCLUSION}

This study reports an endemic honey from Ombulak, Tuzluca, Iğdır - Turkey. This region is a mountainous, sparsely populated and isolated from industrial presence. To the best of our knowledge, a honey from this region is reported for the first time. Results indicate that honey has a fair antioxidant 
and antidiabetic character as well as a nitrite/nitrate ratio higher than 1.0. Although many kinds of honey have antidiabetic activity, as in the case of Iğdir honey, larger clinical studies are needed to make honey an alternative to sugar for diabetics. Further studies by medical scientists or biologists might reveal the biological characteristics of this type of honey.

\section{ACKNOWLEDGEMENTS}

The author would like to thank Mr. Firuz Iğdır for supplying the honey samples and Prof. Dr. F. Bedia Erim and Ms. Zeynep Kalaycığlu for providing the research facility.

\section{REFERENCES}

Anonymous, 2003. Nitrate and nitrite in drinking-water: background document for development of World Health Organization (WHO) guidelines for drinking-water quality

Beretta G, Gelmini F, Lodi V, Piazzalunga A, Maffei Facino R. 2010. Profile of nitric oxide (NO) metabolites (nitrate, nitrite and $\mathrm{N}$-nitroso groups) in honeys of different botanical origins: Nitrate accumulation as index of origin, quality and of therapeutic opportunities. Journal of Pharmaceutical and Biomedical Analysis, 53(3):343-349.

Blois MS. 1958. Antioxidant determinations by the use of a stable free radical. Nature, 181(4617):1199-1200.

Bryan NS, Alexander DD, Coughlin JR, Milkowski AL, Boffetta P. 2012. Ingested nitrate and nitrite and stomach cancer risk: An updated review. Food and Chemical Toxicology, 50(10):3646-3665.

Dağ B, Sıralı R, Tarakçı Z. 2017. Investigation Of Some Properties Of Chestnut Honey Produced In Black Sea Region Of Turkey. Batman University Journal of Life Sciences, 7(2/2):118-123.

Dümen E, Akkaya H, Öz GM, Sezgin FH. 2013. Microbiological and parasitological quality of honey produced in İstanbul. Turkish Journal of Veterinary and Animal Sciences, 37:602-607.

Erejuwa OO, Sulaiman SA, Ab Wahab MS. 2012. Honey - A novel antidiabetic agent. International Journal of Biological Sciences, 8(6):913-934.

Erez ME, Karabacak O, Kayci L, Fidan M, Kaya Y. 2015. Characterization of Multifloral Honeys of Pervari Region with Different Properties. Türkiye Tarımsal Araştırmalar Dergisi, 2:40-46.

Gül A, Pehlivan T. 2018. Antioxidant activities of some monofloral honey types produced across Turkey. Saudi Journal of Biological Sciences, 25(6):1056-1065.

Iammarino M, Di Taranto A, Cristino M. 2014. Monitoring of nitrites and nitrates levels in leafy vegetables (spinach and lettuce): a contribution to risk assessment. Journal of the Science of Food and Agriculture, 94(4):773-778.

Kalaycioğlu Z, Erim FB. 2016. Simultaneous Determination of Nitrate and Nitrite in Fish Products with Improved Sensitivity by Sample Stacking-Capillary Electrophoresis. Food Analytical Methods, 9(3):706-711.

Kalaycıoğlu Z, Erim FB. 2017. Total phenolic contents, antioxidant activities, and bioactive ingredients of juices from pomegranate cultivars worldwide. Food Chemistry, 221:496-507.

Kalaycioğlu Z, Gazioğlu I, Erim FB. 2017a. Comparison of antioxidant, anticholinesterase, and antidiabetic activities of three curcuminoids isolated from Curcuma longa L. Natural Product Research, 31(24):29142917.

Kalaycıŏglu Z, Kaygusuz H, Döker S, Kolaylı S, Erim FB. 2017b. Characterization of Turkish honeybee pollens by principal component analysis based on their individual organic acids, sugars, minerals, and antioxidant activities. LWT - Food Science and Technology, 84.

Kalaycıŏlu Z, Uzaşçı S, Dirmenci T, Erim FB. 2018. $\alpha$-Glucosidase enzyme inhibitory effects and ursolic and oleanolic acid contents of fourteen Anatolian Salvia species. Journal of Pharmaceutical and Biomedical Analysis, 155:284-287.

Kalaycloğlu Z, Erim FB. 2019. Nitrate and Nitrites in Foods: Worldwide Regional Distribution in View of Their Risks and Benefits. Journal of Agricultural and Food Chemistry, 67(26):7205-7222. 
Kaygusuz H, Tezcan F, Bedia Erim F, Yildiz O, Sahin H, Can Z, Kolayli S. 2016. Characterization of Anatolian honeys based on minerals, bioactive components and principal component analysis. LWT - Food Science and Technology, 68.

Kıvrak Ş, Kivrak İ. 2017. Assessment of phenolic profile of Turkish honeys. International Journal of Food Properties, 20(4):864-876.

Kolayli S, Kara M, Tezcan F, Erim FB, Sahin H, Ulusoy E, Aliyazicioglu R. 2010. Comparative study of chemical and biochemical properties of different melon cultivars: Standard, hybrid, and grafted melons. Journal of Agricultural and Food Chemistry, 58(17):9764-9769.

Lundberg JO, Carlstörm M, Larsen FJ, Weitzberg E. 2011. Roles of dietary inorganic nitrate in cardiovascular health and disease. Cardiovascular Research, 89(3):525-532.

Ma L, Hu L, Feng X, Wang S. 2018. Nitrate and nitrite in health and disease. Aging and Disease, 9(5):938-945.

Malkoç M, Kara Y, Özkök A, Ertürk Ö, Kolaylı S. 2019. Karaçalı (Paliurus spina-christi Mill.) Balının Karakteristik Özellikleri. Uludag Bee Journal, 19(1):69-81.

Matin G, Kargar N, Buyukisik HB. 2016. Bio-monitoring of cadmium, lead, arsenic and mercury in industrial districts of Izmir, Turkey by using honey bees, propolis and pine tree leaves. Ecological Engineering, 90:331-335.

Özenirler Ç, Mayda N, Çelemli ÖG, Özkök A, Sorkun K. 2018. Dandelion Honey: A New Monofloral Honey Record For Turkey. Uludag Bee Journal, 18(2):87-93.

Özkök A, Koru Ö, Sorkun K. 2016. Microbiological Analysis and Antibacterial Effects of Turkish Thyme Honey. Bee World, 93(4):98-101.

Özler H. 2015. Melissopalynological Analysis of Honey Samples Belonging to Different Districts of Sinop, Turkey. Mellifera, 15(1):1-11.

Özler H, Cınbırtoğlu Ş, Güney F, Çakıcı N, Türkaslan N. 2019. Physicochemical Analysis Of Some Honey Samples From Konya And Karaman Regions. Arıcılık Araştırma Dergisi / Journal of Apiculture Research, 11(1):1-7.

Özşahin Kireççi AD, Kireççi OA. 2018. Examination of Some Biochemical Properties of Honeys in Mutki (BitlisTurkey). KSÜ Tarım ve Doğa Dergisi, 936-943.

Radia D, Azzedine C, Nicoletta D, Alice B, Chiara M, Albino G, Franco M. 2015. Physicochemical parameters and antibiotics residuals in Algerian honey. African Journal of Biotechnology, 14(14):1242-1251.

Shai LJ, Magano SR, Lebelo SL, Mogale AM. 2011. Inhibitory effects of five medicinal plants on rat alphaglucosidase: comparison with their effects on yeast alpha-glucosidase. Journal of Medicinal Plants Research, 5(13):2863-2867.

Silici S. 2011. Determination of volatile compounds of pine honeys. Turkish Journal of Biology, 35:641-645.

El Sohaimy SA, Masry SHD, Shehata MG. 2015. Physicochemical characteristics of honey from different origins. Annals of Agricultural Sciences, 60(2):279-287.

Sorkun K. 2008. Türkiye'nin Nektarlı Bitkileri, Polenleri ve Balları. Palme Yayıncılık.

Ünübol Aypak S, İnci A, Bakırc1 S, Dereli Fidan E, Soysal M. 2019. Comparision of the Antioxidant Activity and Hydroxymethylfurfural (HMF) Levels in Honey Taken from Hives and Markets. Gida The Journal of Food, 44(1):86-92. 